\title{
Morphological Characteristics of the Ice Margins of Antarctic Ice Shelf and Outlet Glacier Extracted from ICESat Laser Altimetry Along-Track Profiles
}

\author{
Jieun $\mathrm{Kim}^{1}$, Jaehyung $\mathrm{Yu}^{2, *}$, Lei Wang ${ }^{3}$, Hongxing Liu ${ }^{4}$, and Haein Shin ${ }^{1}$ \\ ${ }^{1}$ Department of Astronomy, Space Science and Geology, Chungnam National University, Daejeon, Korea \\ ${ }^{2}$ Department of Geology \& Earth Environmental Sciences, Chungnam National University, Daejeon, Korea \\ ${ }^{3}$ Department of Geography \& Anthropology, Louisiana State University, Louisiana, U.S.A. \\ ${ }^{4}$ Department of Geography, University of Cincinnati, Ohio, U.S.A.
}

Received 2 June 2015, revised 14 December 2015, accepted 24 December 2015

\begin{abstract}
The Antarctic ice sheet topography including elevation and slope is a key parameter for understanding ice sheet dynamics because the surface slope is a major controller of the ice flow gravitational driving stress magnitude. This study used Ice, Cloud, and land Elevation Satellite (ICESat) laser altimetry data to analyze the ice margin morphological parameters for 20 ice shelves and 12 outlet glaciers distributed over Antarctica. The bottom-up segmentation algorithm application effectively extracted the morphological parameters from the laser altimetry profiles. The ice shelves had an average boundary elevation of $29.5 \mathrm{~m}$ and a slope of $7.8^{\circ}$, with a decreasing surface slope pattern from the boundary to the inner side. The average number of segments and the length of the coastal margin for ice shelves extracted from the bottom-up segmentation algorithm is 3.2 and is $18.4 \mathrm{~km}$, respectively. The outlet glaciers had a boundary elevation of $29.7 \mathrm{~m}$ with a slope of $7.4^{\circ}$. The average number of segments for outlet glaciers is 5.03 , and the distance to the margin is $10.38 \mathrm{~km}$. The outlet glaciers were of two types. The first type had a higher ice margin slope, a shorter ice margin distance and concave shape to the surface profile. The second type had a much shorter ice margin distance and an undulating surface profile shape. The ice margin morphology shows distinctive characteristics depending on the major ice loss process.
\end{abstract}

Key words: Morphological characteristic, Laser altimetry profile, Bottom-up segmentation algorithm

Citation: Kim, J., J. Yu, L. Wang, H. Liu, and H. Shin, 2016: Morphological characteristics of the ice margins of Antarctic ice shelf and outlet glacier extracted from ICESat laser altimetry along-track profiles. Terr. Atmos. Ocean. Sci., 27, 451-462, doi: 10.3319/TAO.2015.12.24.01(ISRS)

\section{INTRODUCTION}

The Antarctic ice sheet plays an important role in climate change research because the cryosphere integrates climate variations over a wide range of time scales. The Antarctic ice sheet visibly expresses climate change; consequently, significant research efforts have focused on identifying the climate change signals in Antarctica (Lemke et al. 2007). The Antarctic ice margins are in direct contact with the ocean as well as the atmosphere; thus, they are among the first places affected by global climate change. Knowledge of the ice margins along the Antarctic coast can aid in the interpretation of global climate change (Bamber and Payne 2004). There is a consensus that the Antarctic sheets have negative mass balance (Vaughan et al. 2013). How-

\footnotetext{
* Corresponding author

E-mail:jaeyu@cnu.ac.kr
}

ever, the magnitude and the reason for this trend are not yet clarified. The ice sheet observation time series and detailed observations of ice thickness, surface elevation, and basal boundary conditions will enable mass ice sheet change predictions (Wouters et al. 2013; Young et al. 2015).

The Antarctic coast line can be classified into four features: the ice shelf/front, the outlet glacier/ice stream, the ice wall/ice cliff, and ice-free rocks (Fox et al. 1994). An ice shelf is an ice platform that floats on the ocean. It is formed by the down flow of a glacier or ice sheet. Over $48 \%$ of the Antarctic coast is associated with ice shelves. The outlet glacier is an ice stream generated by ice sheet discharges directly into the ocean. It often forms glacier tongues as it discharges. Outlet glaciers account for over $8 \%$ of the Antarctic coast line. An ice cliff is a grounded ice sheet that terminates abruptly at the ocean. Ice cliffs account for about $37 \%$ of the Antarctic coast. Ice-free rock surfaces occupy about $6 \%$ of 
the Antarctic coast line (Fox et al. 1994). Among the Antarctic coast types, the ice shelf and outlet glaciers have been most thoroughly studied as they are the most dynamic and variable features and are believed to be sensitive to climate change (Williams and Ferrigno 1998). A previous estimation indicated that $62 \%$ of iceberg calving transported to the Antarctic coast arises from ice shelves, $22 \%$ from outlet glaciers, and 16\% from ice cliffs (Drewry and Cooper 1981).

The ice sheet topography including elevation and slope is a key parameter for understanding ice sheet dynamics because the surface slope is a major controller of the ice flow gravitational driving stress magnitude (Paterson 1994; Fahnestock and Bamber 2001). Most of the topographical studies on the Antarctic coast are focused on outlet glaciers since the outlet velocity variations affects the ice sheet surface profile and are correlated with the bedrock topography (Marshall et al. 1996; Rémy and Minster 1997). However, the topographical characteristics of the Antarctic ice shelf and outlet glaciers have not been quantitatively analyzed. This study presents a quantitative analysis of the topographic characteristics of Antarctic ice shelves and outlet glaciers, employing Ice, Cloud, and land Elevation Satellite (ICESat) along track profiles. Moreover, their topographic characteristics are correlated with ice velocity to determine the relationship between the topography and ice dynamics.

\section{DATA SETS}

We classified ICESat along-track data representing each type of coast according to Modified Antarctic Mapping Mission (MAMM) (Jezek 2008) data. Once classified, the ICESat tracks of ice shelves and outlet glaciers were topographically analyzed. The relationship between surface morphology and ice velocity was analyzed for ice shelves and outlet glaciers. We utilized the MEaSUREs InSARBased Antarctica Ice Velocity Map (Rignot et al. 2011) for ice velocity and ice sheet topography analysis.

The RADARSAT-1 Antarctic Mapping Project was conducted to map Antarctica using synthetic aperture radar. The RADARSAT SAR image has a $25 \mathrm{~m}$ resolution and the data permit coastal dynamics examination with all weather radar capability (Jezek 2008). The MAMM employing the RADARSAT satellite was conducted from September to November 2000 to generate a high resolution SAR image map of the entire continent of Antarctica. The MAMM has collected data from $80.1^{\circ} \mathrm{S}$ latitude to the coast (Jezek et al. 2003) and the single mosaic image used in this study has a spatial resolution of $100 \mathrm{~m}$. We overlaid every ICESat along track data onto the MAMM image to classify each track to the appropriate Antarctic coast type.

The Geoscience Laser Altimeter System (GLAS) mounted on the ICESat, has collected 18 laser accurate elevation measurement campaign operations up to latitude $86^{\circ} \mathrm{S}$. The ICESat mission was designed to work for three to five years, launched in January 2003. To complete the mission, the GLAS carried three lasers to fulfill the mission length. After the first laser was activated, GLAS measured laser waveforms, surface elevations, clouds, and aerosols perfectly. However, during the beginning of on orbit test operations, a pump diode module on the first GLAS laser failed in March 2003. Due to the corrosive degradation of the pump diodes, the laser reliability was reduced. As a result, the operational plan for GLAS was changed, and it was operated for one month periods out of every three to six months to extend duration of measurement. The last GLAS laser was stopped in October 2009, and the satellite stopped working in February 2010 (Kichak 2003; Schutz et al. 2005). The ICESat laser altimetry data are among the most accurate topographic measurements obtained by satellite altimeters, with horizontal geolocation accuracy of $6 \mathrm{~m}$ (Schutz et al. 2005 ) and a relative vertical accuracy of $14 \mathrm{~cm}$ (Shuman et al. 2006). A $65 \mathrm{~m}$ footprint and sampling spacing of about $172 \mathrm{~m}$ along satellite orbits provide relatively dense measurements appropriate for topographic analysis (Schutz et al. 2005). The ICESat was in an orbit that repeated ground tracks every 8 days for calibration and validation purposes. Thus the acquired ICESat laser altimetry data is temporally sporadic. During the mission phases, GLAS has acquired data from a specific portion of a 91-day orbital pattern. The ICESat also has a 33-day sub-cycle orbit of the 91-day pattern. This sub-cycle orbit was selected as an adjustment to accomplish the goals given that ICESat cannot be operated continuously as it designed to do (Massom and Lubin 2006). The ICESat measured the distance between the surface and satellite using laser pulse and transmission time delay. The ice sheets and land have wide waveform windows due to the complicated surface features. The waveform quality is important to determine surface elevation. In the pre-light ground test by Yi et al. (2003), a $2.0 \mathrm{~cm}$ range of uncertainty was estimated. The waveforms are could be effected by pulse energy, atmospheric attenuation, surface reflectivity, slope, and roughness and it also affects the elevation accuracy and surface elevation location. However, the $2.0 \mathrm{~cm}$ of precision estimated in pre-light ground test was also confirmed by Kwok et al. (2004) and Shuman et al. (2006) regarding the flat ice sheet surface and sea ice polynya as $2.0 \mathrm{~cm}$ of noise level (Zwally et al. 2008). Therefore, the ICESat laser altimetry data accuracy is satisfactory for calculating surface elevation and slope. We extracted the original ICESat laser altimetry data (V31) along satellite tracks covering the Antarctic coast and processed 778 along-track profiles to analyze the topographic characteristics (Fig. 1).

During the International Polar Year 2007 to 2009, the National Snow and Ice Data Center (NSIDC) assembled multiple satellite interferometric synthetic-aperture radar data and published a comprehensive, high-resolution, digital mosaic of ice motion in Antarctica named the MEaSUREs InSARBased Antarctica Ice Velocity Map (Rignot et al. 2011). The 
velocity data are an assemblage of 900 satellite tracks and more than 3000 orbits of radar data with a horizontal precision of $300 \mathrm{~m}$. The nominal errors range from $1 \mathrm{~m} \mathrm{yr}^{-1}$ to about $17 \mathrm{~m} \mathrm{yr}^{-1}$ (Rignot et al. 2011). We used these data to analyze the relationship between the topographic characteristics of the outlet glaciers/ice shelves and ice dynamics.

\section{SURFACE MORPHOLOGY EXTRACTION FROM ICESAT ALONG TRACK PROFILES}

\subsection{A Summary of the Morphological Characteristics Using Arbitrarily Selected Profile Length}

The ice sheet topographic parameters such as elevation and slope can provide important information about ice dynamics. More importantly, morphological characteristics at the boundary condition infer the ice dynamics of the outlet glaciers and ice shelves. We summarized the morphological characteristics of the Antarctic coast by extracting ICESat measurements close to the Antarctic coast line. Ice margins can be identified using local vertical data and the boundary where elevation points emerge from the sea level. This is further confirmed using the LIMA/MAMM images. The elevation and is recorded at these identified ice margins to provide morphological characteristics of the boundary condition between the ocean and the ice fronts of the Antarctic coast. Further, elevation measures are recorded from ICESat along-track profiles at locations extending from the ice margin points at $500 \mathrm{~m}, 1 \mathrm{~km}$, and $5 \mathrm{~km}$. The slope values are calculated from the elevation recorded from ICESat along-track profiles and horizontal distance using the ratio of elevation change to the horizontal change at the boundary locations, $500 \mathrm{~m}, 1 \mathrm{~km}$, and $5 \mathrm{~km}$.

The practice of manually extracting coastal morphology features using arbitrarily selected locations is problem- atic. First, the arbitrary values $(500 \mathrm{~m}, 1 \mathrm{~km}$, and $5 \mathrm{~km}$ ) cannot ensure the capture of morphology features because of the highly heterogeneous nature of the Antarctic coast. The elevation and slope records may therefore not represent any characteristics of the actual coast morphology. Second, the satellite tracks are not always perpendicular to the coastline. The variability in the track incident angle creates difficulties in selecting the thresholds as arbitrary values. Third, the numerous ICESat tracks and the enormous Antarctica area make this manual procedure tedious and fallible. To deal with this issue, we incorporated a bottom-up (BU) segmentation algorithm to characterize the morphological features of the Antarctic coast.

\subsection{BU Segmentation}

Since Bruun (1954) brought up the classic power function expression, many researchers have presented their equations for numerical representation of beach profiles, either by extending the power function, such as Dean (1977, 1991), Wang and Davis (1998), Larson et al. (1999), or using exponential functions (Bodge 1992; Komar and McDougal 1994). However, as argued in Huang et al. (2010), the monotonic decreasing properties is the obstacle to realistically represent coastal morphologic features. Huang et al. (2015) instead proposed a piecewise polynomial interpolation function (PWPIF) representation. The PWPIF method can overcome the over fluctuation problem of the cubic spline method when there are sharp topographical changes in the profile, by enforcing a weighted average with a linear function. The polynomial equations ensemble, however, lacks physical meaning for the portion of the beach profile that they represent. Therefore, in similar spirit, we propose presenting a piecewise beach profile

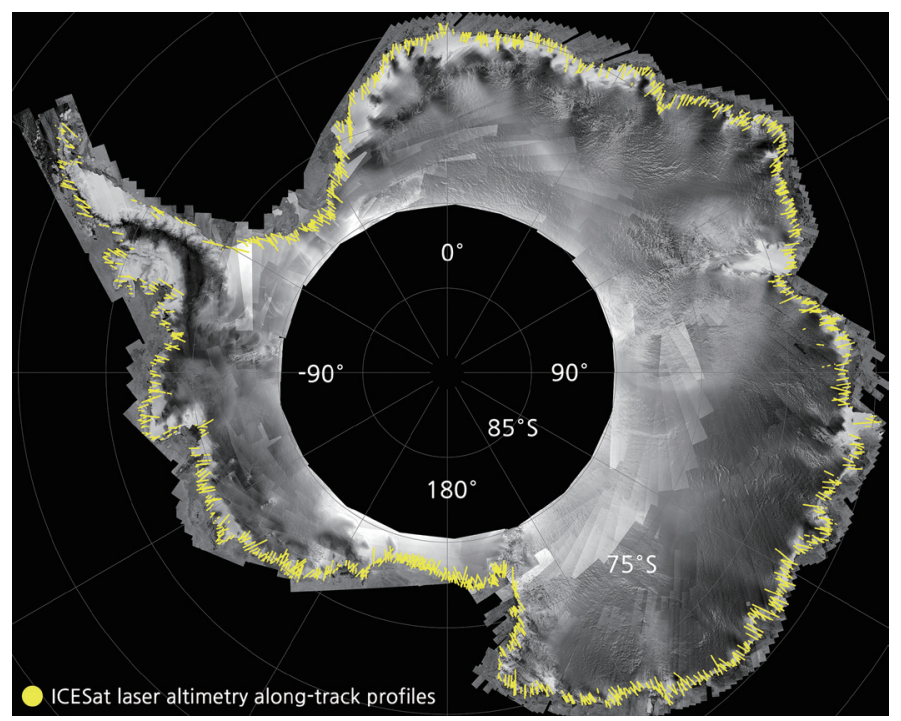

Fig. 1.778 ICESat laser altimetry along-track profiles overlaid onto an MAMM image mosaic. (Color online only) 
linear representation calculated using the BU segmentation algorithm (Wang and Yu 2011), for an effective beach profile morphological analysis. Wang and Yu (2011) introduced this method for extracting thematic information from temporally continuous observation satellite data. The common objectives in this study mean that the same algorithm can be applied to the profile data from the ICESat data. The BU algorithm groups the neighboring elevation points in a profile as linear segments to approximate the discrete elevation points.

The initial stage of the algorithm defines the smallest profile segmentation. At this stage, linear segments are defined between any adjacent topological points and are recorded by the algorithm.

Iteratively, smaller segments are merged to form larger ones as long as the approximation error is smaller than a specified value. The merging of smaller segments is ordered by a priority defined as the merging cost, where the adjacent segments with the least merging cost will be merged at each iteration. The merging cost is calculated using the linear regression chi-square function on the larger segment to be formed:

$x^{2}=\sum_{l=1}^{N}\left[\frac{E_{l}-\left(a_{l}+b\right)}{\sigma_{l}}\right]^{2}$

Where $l$ is the location, $E_{l}$ is the elevation value at location, $a$ and $b$ are coefficients to be estimated from the least squares fitting, and $\sigma_{l}$ is the measurement error at location 1, which is set to one because the error distribution is unknown.

A stopping condition is defined to end the iterative procedure. If the least merging cost is smaller than a specified threshold, step (2) will be executed. Otherwise, when all merging costs are greater than the threshold value, the algorithm ends. The segments can represent specific morphology features; for example, a flat ice sheet extending into the ocean from the ground line. The segmentation enables characterization of the coast morphology by the quintiles and statistics such as the slope, length and standard deviation of the mean.

As a result, each ICESat topographic profile is broken into a number of topographic segments. The greater number of segments indicates more topographic variations. The breakpoints between the segments are morphological feature points, such as the water/ice interface. The segmentation provides a coast morphology characterization with multiple variables, including the number of segments, length, mean elevation, slope, and standard deviation of the elevation, as well as the elevations at the starting and ending breakpoints of the segments.

Based on the BU algorithm, a total of 289 and 29 tracks were used for topographic analysis of ice shelves and outlet glaciers, respectively. We ultimately summarized the topographic characteristics of 20 ice shelves and 12 outlet glaciers distributed over Antarctica (Fig. 2). Note that the slope value for the boundary condition in this study is underestimated due to the relatively longer sampling spacing of $172 \mathrm{~m}$ compared to the ice margin elevation. However, the slope values still provide significant information relative to each

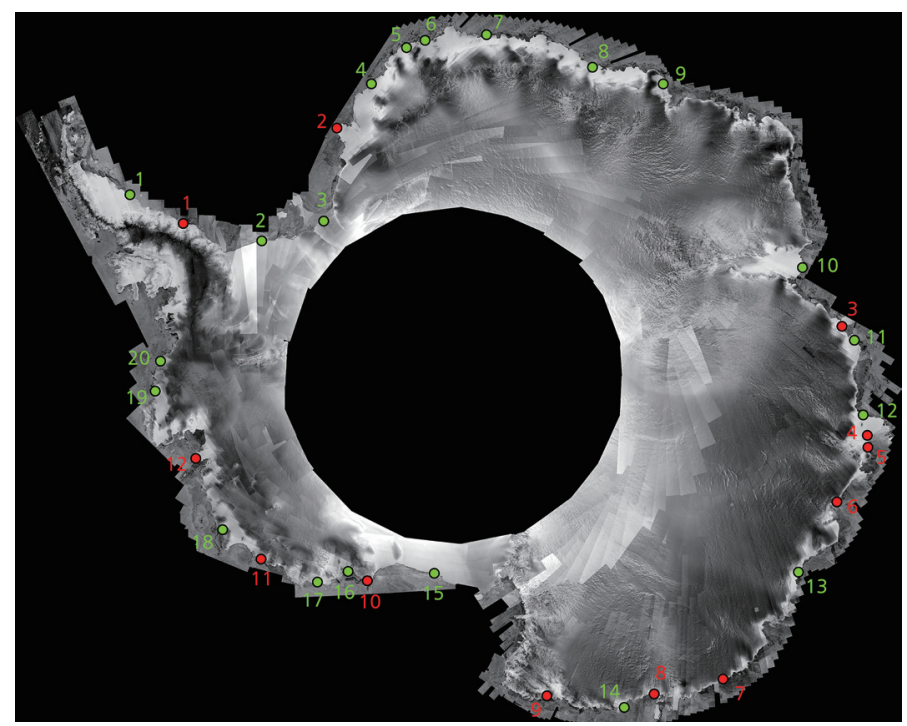

Fig. 2. Location map of the Antarctic ice shelves and outlet glaciers analyzed in this study. Ice Shelves (Green): (1) Larsen Ice Shelf; (2) Ronne Ice Shelf; (3) Filchner Ice Shelf; (4) Riiser-Larsen Ice Shelf; (5) Ekstrom Ice Shelf; (6) Jelbart Ice Shelf; (7) Fimbul Ice Shelf; (8) Lazarev Ice Shelf; (9) Prince Harald Coast; (10) Amery Ice Shelf; (11) West Ice shelf; (12) Shackleton Ice Shelf; (13) Sabrina Coast; (14) Cook Ice Shelf; (15) Ross Ice Shelf; (16) Sulzberger Ice Shelf; (17) Nickerson Ice Shelf; (18) Getz Ice Shelf; (19) Abbot Ice Shelf; (20) Venable Ice Shelf. Outlet Glaciers (Red): (1) Bulter Inlet; (2) Thwaites Glacier; (3) Sorsdal Glacier; (4) Denman Glacier; (5) Scott Glacier; (6) Underwood Glacier; (7) Dibble Glacier; (8) Ninnis Glacier; (9) Lille Glacier; (10) Bartlett Glacier; (11) Williamson Glacier; (12) Tompson Glacier. (Color online only) 
other, since the same condition is applied for all tracks.

\section{MORPHOLOGICAL CHARACTERISTICS OF ICE SHELVES}

Ice shelves are very flat, with a relatively stiff ice front that forms the boundary location between the ice margin and the ocean. Jenkins and Doake (1991) reported a variation of only a few meters over the central $400 \mathrm{~km}$ of the Ross Ice Shelf, while the Ronne Ice Shelf showed a larger variation of $25 \mathrm{~m}$ because of its substantial basal melting and freezing. Our analysis coincides well with these previous studies. Overall, ice shelves had a boundary elevation of $29.51 \mathrm{~m}$, with a slope of $7.75^{\circ}$ (Table 1). As the profiles moved into the inner sides of the ice shelves, the slopes flattened and showed a decreasing pattern of angles from 0.4 to $0.2^{\circ}$ at the $5 \mathrm{~km}$ location. Their relatively smaller topographic variation meant that these ice margin segments were identified as very long lasting ends of the ICESat tracks, with an average distance of $18.4 \mathrm{~km}$ and a slope of $0.5^{\circ}$ (Table 1). Among the 20 ice shelves analyzed in this study, the Filchner Ice Shelf had the highest boundary elevation of $40.5 \mathrm{~m}$, while the Sulzberger Ice Shelf had a boundary elevation of only $5.27 \mathrm{~m}$, inferring that large variations in boundary elevation occurred by location.

Previous studies reported an extremely flat topography for the central part of the ice shelves. However, we noted a different story for the ice margins of the ice shelves. Within $5 \mathrm{~km}$ of the ice margin from the ice front, the overall average elevation increased from $29.5-55.3 \mathrm{~m}$ which is more than a $40 \%$ elevation change (Table 1). Therefore, the traditional shape is not acceptable regarding the ice margin of ice shelves. The boundary elevation also varied by location within the same ice shelf. For example, the Filchner Ice Shelf has a $40.5 \mathrm{~m}$ boundary elevation with a standard deviation of $15 \mathrm{~m}$ and the elevation increases to $49.6 \mathrm{~m}$ at $500 \mathrm{~m}$ on the inner side, with a smaller standard deviation. The slope between the two locations is quite steep. We selected four profiles that crossed the ice margin of the Filchner Ice Shelf, and all four showed significant changes in elevation while the boundary elevation varies by location (Fig. 3a). The figure shows two profiles with gradual changes, indicated as a series of color code changes which indicate significant increases in elevation as the profile moves inside (Fig. 3b). The surface elevation of an ice shelf infers the ice thickness for the ice shelf, and the ice thinning occurring at ice shelves is considered to represent basal melting ( $\mathrm{Yu}$ et al. 2010). Therefore, the profiles indicate a considerable amount of thinning occurring at the ice front, while the thinning decreases at the inner side, which may also indicate active basal melting at the boundary.

On the other hand, the other two profiles were related to the ice calving process. One track detected an iceberg calved from the ice front as the elevation fluctuated from
45, 60 to $0 \mathrm{~m}$ elevation, inferring about a $3 \mathrm{~km}$ diameter for the iceberg (Fig. 3a). The other track crosses the active rift system, which is considered to be closely related to iceberg calving activities (Fricker et al. 2005). Indeed, the profile and MAMM image show active ice calving in progress (Fig. 3a). These two profiles differ substantially from the two profiles previously described as they show an abrupt increase in elevation at the boundary and their elevation variations are smaller (Fig. 3a). As iceberg calving occurs, the basal melting that takes place at the fresh ice front is not significant to cause ice thinning.

Figures $3 \mathrm{c}$ and $\mathrm{d}$ show that the Shackleton ice shelf is experiencing severe iceberg calving. The ICESat along track profile clearly identifies micro rift systems that are causing vigorous ice calving activities at that location. The rift intervals vary from $1-3 \mathrm{~km}$, with no visible trend in surface elevation. We were unable to find any locations indicating ice thinning by basal melting. This supports our previous arguments regarding minimal basal melting, where the ice calving process is the main ice loss mechanism for ice shelves. Many studies have discussed that iceberg calving and basal melting processes are the main ice loss mechanisms for ice shelves (e.g., Yu et al. 2010). The present analysis infers a close relationship between the two ice loss processes at the ice fronts. For the retreating ice shelves, ice calving could be the major ice loss process, while active basal melting at the ice front would be the main ice loss mechanism where iceberg calving is minimal. Indeed, the Larsen ice shelf, which is known to be retreating, also shows the same trend toward broad variations in ice margin elevation (Cook et al. 2005). By contrast, the Amery ice shelf, which is advancing, shows minimal variations at the boundary ( $\mathrm{Yu}$ et al. 2010).

The major driving force for glacier movement and ice streams is gravity caused by ice thickness and surface slope. In general, if the ice thickness is large and the surface slope is high, high driving stresses are created for a grounded ice sheet (Echelmeyer et al. 1991). The ice flow is restrained by forces that oppose the gravitational driving force. These forces are caused mainly by the shear stress between the ice and the bed rock. However, floating ice shelves have a basal shear of zero, and the restraint is caused mainly by the shear between the ice shelf and its margins (Robin et al. 1983). Therefore, in general, the highest ice shelf velocity is recorded at the central location of the ice shelf.

The ice flux near the ice front location where ice calving occurs is not known with certainty (Massom and Lubin 2006). We recognized this ice front dynamics uncertainty, so we examined whether the ice surface morphology contributes in any way to the ice dynamics by plotting the ice velocity at our ICEsat track locations and the ice margin elevation and slope (Fig. 4). Among the ice shelves analyzed in this study, the Filchner, Amery, and Cook ice shelves had the highest ice velocity of 1074,770 , and $714 \mathrm{~m} \mathrm{yr}^{-1}$, respectively, while they had average boundary elevation of 40,30 , 


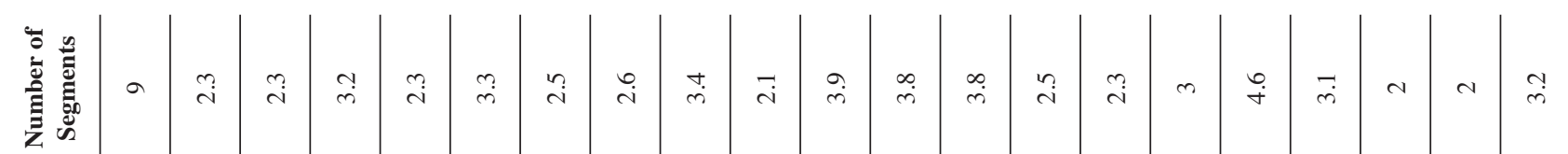

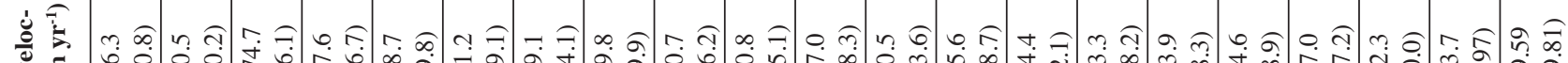
总至

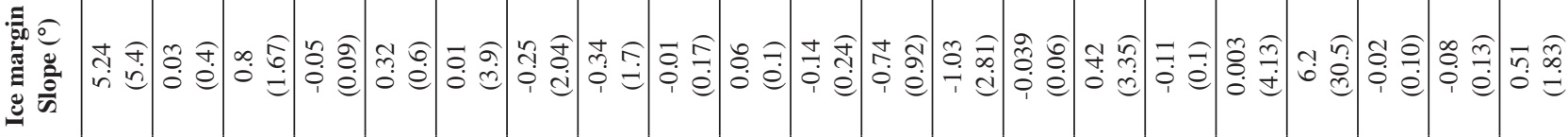

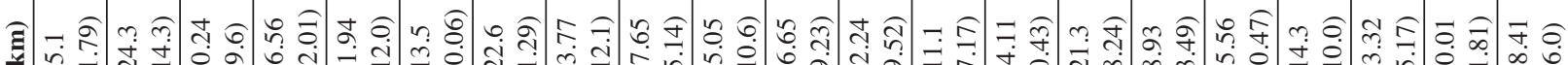

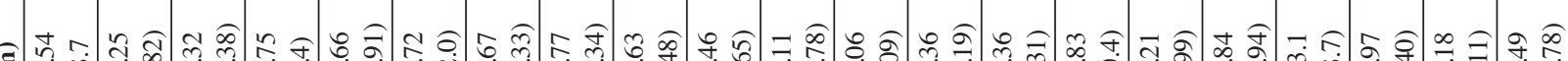

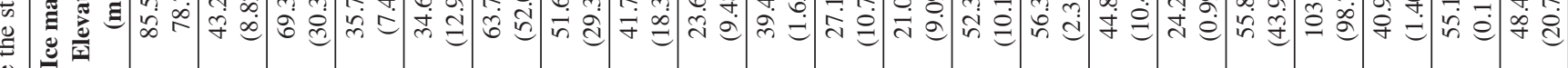
일

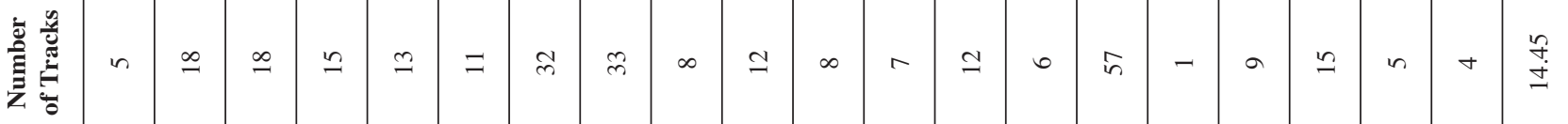

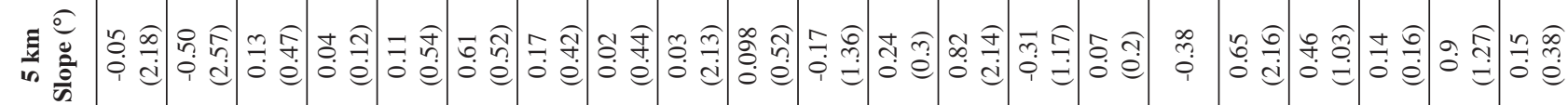

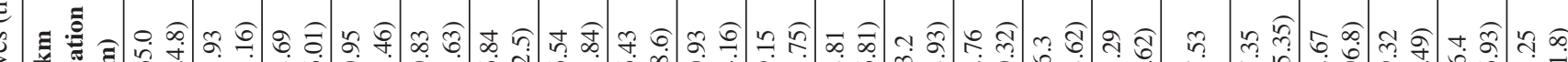

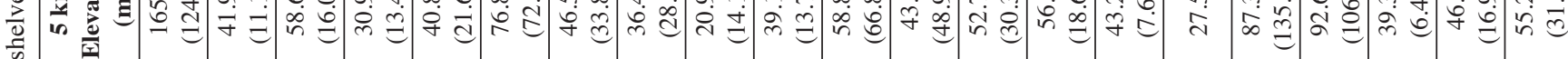

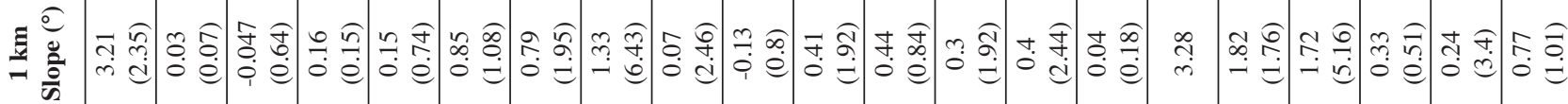

घ

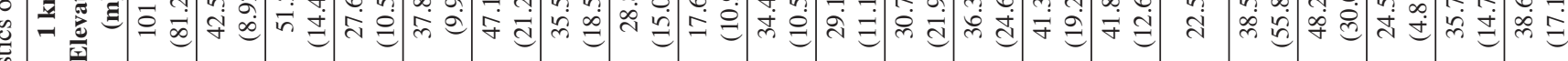

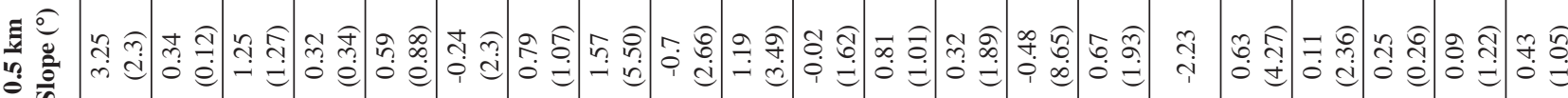

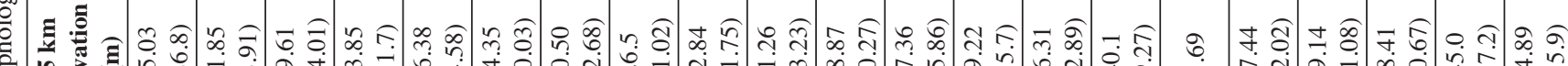
¿.

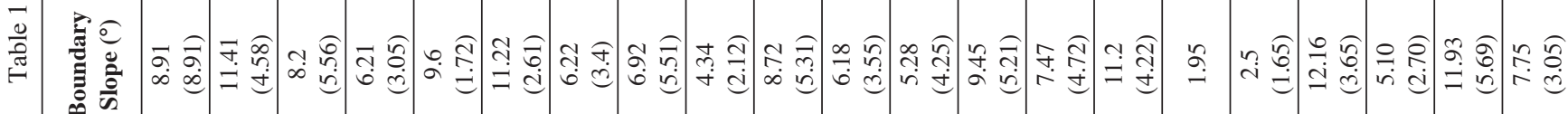

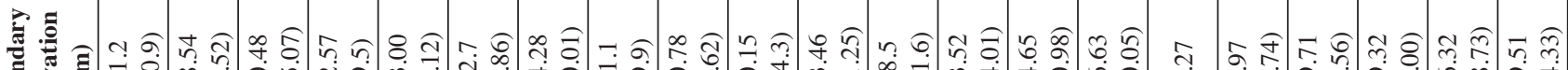
言践

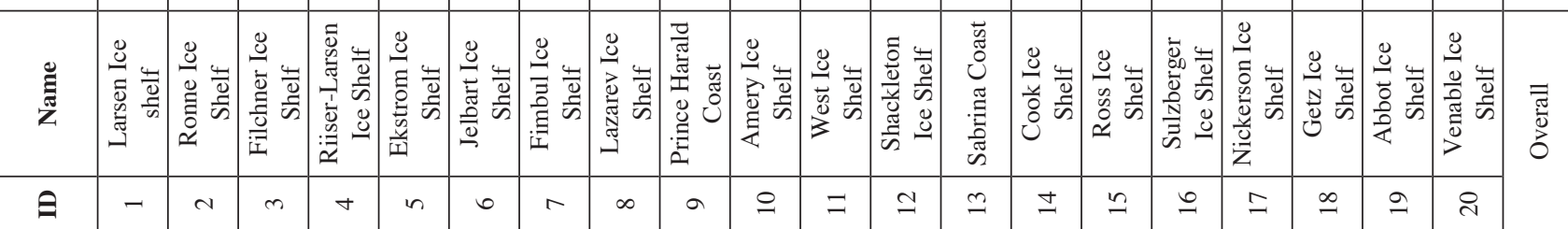


(a)

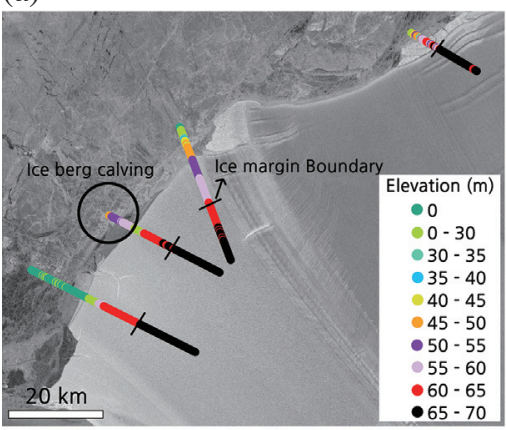

(c)

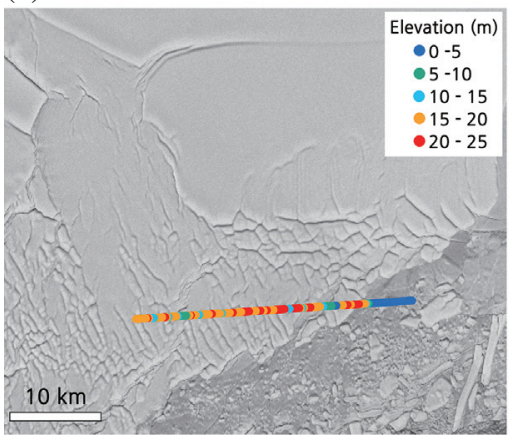

(b)

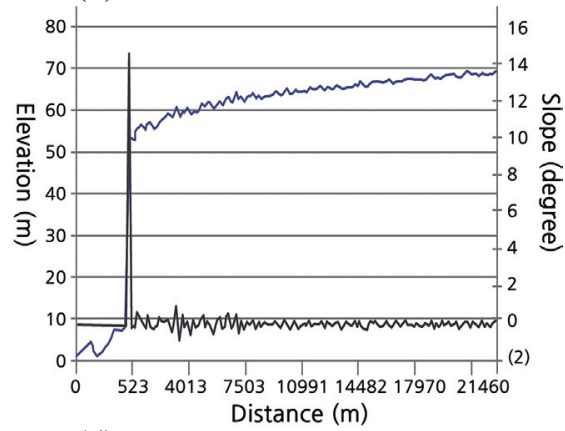

(d)

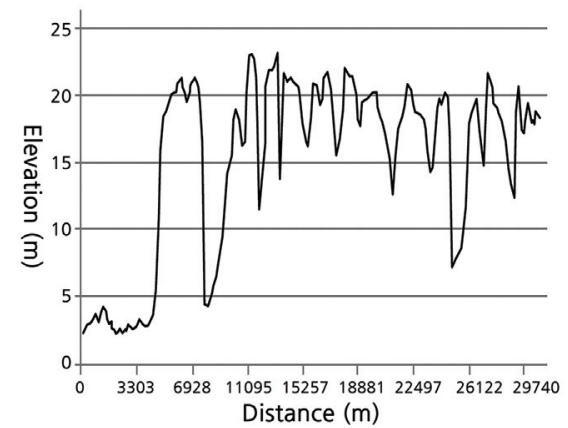

Fig. 3. Two different types of ice shelf profiles: (a) ICESat laser altimetry profiles of the Filchner ice shelf overlaid on MAMM data; (b) representative ICESat laser altimetry profile of the Filchner ice shelf; (c) ICESat laser altimetry profile of the Shackleton ice shelf overlaid on MAMM data; and (d) ICESat laser altimetry profile of the Shackleton ice shelf. (Color online only)

(a)

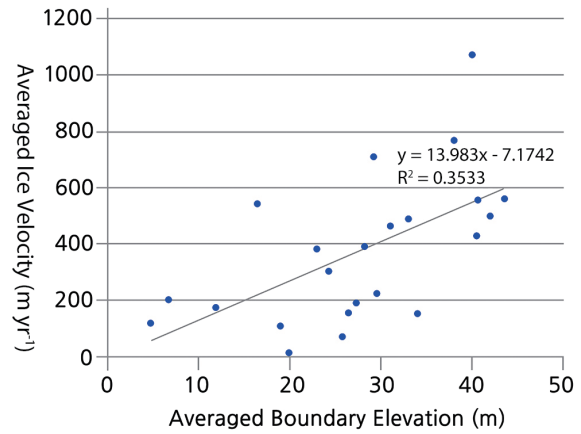

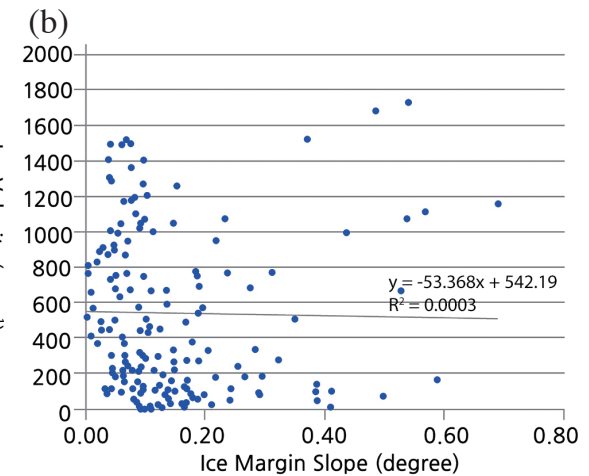

Fig. 4. Scatterplots of ice velocity and topographic parameters of ice shelves; (a) boundary elevation, and (b) ice margin slope. (Color online only)

and $25 \mathrm{~m}$ respectively (Table 1). These three ice shelves are in the group with the highest boundary elevation, which may indicate a positive relationship between the boundary elevation (ice thickness) and ice velocity. Our interpretation is that the ice shelf thickness may be related to the ice dynamics (Fig. 4a). However, even if ice thickness is related to ice dynamics, the surface elevation does not take into consideration the shear strain, which may slow down the ice movement. The ice margin slope showed no relationship (i.e., a very low correlation coefficient) (Fig. 4b), which infers that the ice margin slope of the ice shelves would not be a significant parameter in their ice dynamics.

\section{MORPHOLOGICAL CHARACTERISTICS OF OUTLET GLACIERS}

As previously mentioned, outlet glaciers and glacier tongues are very dynamic and changeable features. Unlike ice shelves, outlet glaciers have relatively larger topographic variation which means this type of coastal margin has short floating ice flows with higher ice margin slopes. The shorter floating ice range, active crevasse development, and higher inner slope results in the appearance of many topographic segments (an average number of 5) in the outlet glacier and a shorter ice margin distance of $10.4 \mathrm{~km}$ (Table 2). 
焉

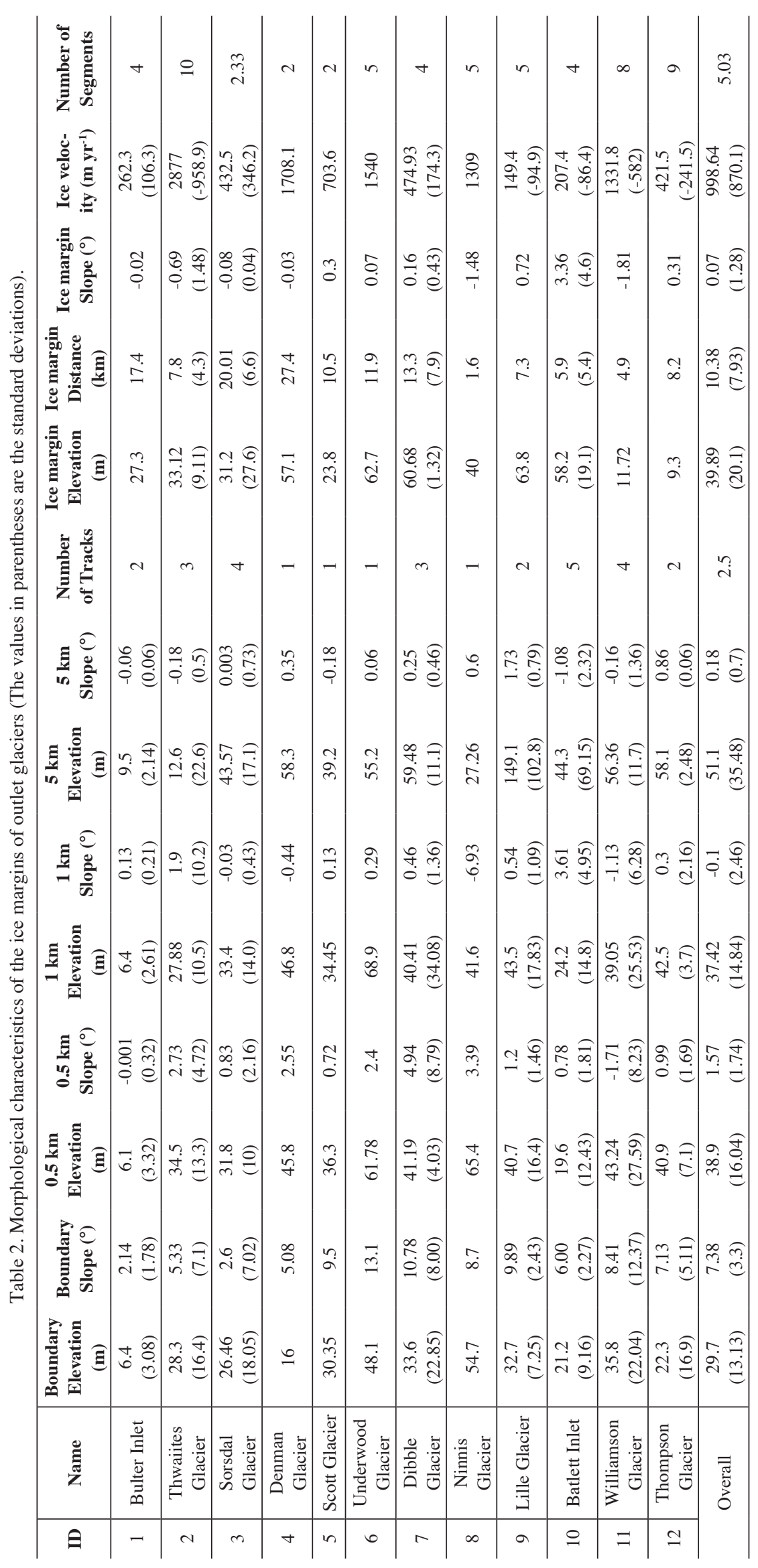


The outlet glacier velocity affects the entire ice sheet profile; thus, the outflow conditions may affect the shape of the ice sheet topography (Drewry and Robin 1983; Marshall et al. 1996). Overall, the outlet glacier boundary elevation examined in this study was $29.7 \mathrm{~m}$, with a $7.38^{\circ}$ slope. The ice margin elevation gradually increased to $39.9 \mathrm{~m}$, with an average slope of $0.2^{\circ}$ at $5 \mathrm{~km}$, as the profile moved toward the upslope of the outlet glaciers (Table 2).

A significant number of outlet glaciers experience active iceberg calving and discharge at the ice margin, so the ice margin topography varies substantially and can be summarized into two distinctive types. The first outlet glacier type discharges ice directly into the ocean at the glacier terminus directly without floating. The Lille glacier is an example (Fig. 5a). This type of outlet glacier has a relatively high ice margin slope with a shorter ice margin length compared to the average glacier. The surface profile slope dramatically increases as the profile moves towards the upstream. The Lille glacier shows a boundary slope of $9.9^{\circ}$ and the slope indicates a concave shape with slope values of $1.2-0.54^{\circ}$ up slope. The profile slope dramatically increases to $1.73^{\circ}$ at $5 \mathrm{~km}$ with an ice margin segment length of $7.3 \mathrm{~km}$ (Table 2 and Fig. 5). In general, this type of outlet glacier sits on concave shape surface morphology. This type of profile is expected to occur after major iceberg calving, as the floating part of the ice stream, with its extensive ice crevasses, is detached. The Denman, Dibble and Underwood glaciers have similar profile characteristics as those of the Lille glacier. The Denman glacier shows a boundary slope of $5.08^{\circ}$ and the surface profile has a concave shape from the coast to upstream with slope values of 2.55 to $-0.44^{\circ}$. The Dibble glacier also has a similar profile pattern and a relatively high ice margin slope of $0.16^{\circ}$. The Underwood glacier shows a boundary slope of $13.1^{\circ}$ and the slope has a decreasing pattern from 2.4 to 0.29 to $0.06^{\circ}$ at a $5 \mathrm{~km}$ distance. The Denman, Dibble and Underwood glaciers have high ice margin elevations of $57.1,60.7$, and $62.7 \mathrm{~m}$, respectably.

The second outlet glacier type is characterized by a discharged ice stream that floats and extends into the ocean in the form of a narrow and elongated shape. This type includes ice tongues and shows a similar form as ice shelves, but with a much shorter ice margin and extensive ice crevasse development that causes surface undulations (Fig. 5). These frequent undulations result in profiles consisting of a relatively large number of segments, with slopes that alternate between positive and negative until the profile reaches the grounded glacier upstream. Figure 5 shows that the Scott glacier has similar patterns as those of ice shelves experiencing active iceberg calving and this pattern also appears in the Williamson and Bulter inlet. The Williamson glacier has a shorter ice margin distance of $4.9 \mathrm{~km}$, a boundary elevation of $35.8 \mathrm{~m}$, and a boundary slope of $8.41^{\circ}$, and its elevation fluctuates from 43.2 to 39.1 to $56.4 \mathrm{~m}$. The Bulter inlet has a boundary slope of $2.1^{\circ}$ and the profile slope changes (a)

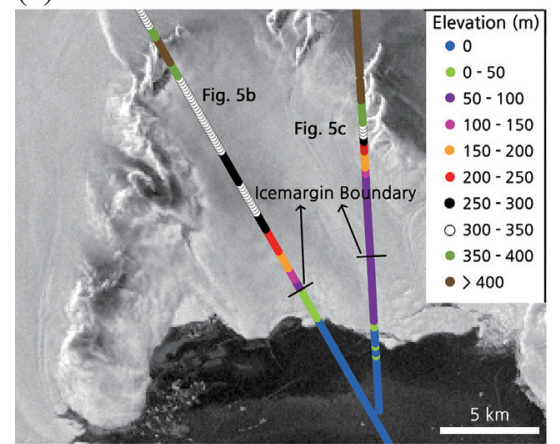

(d)

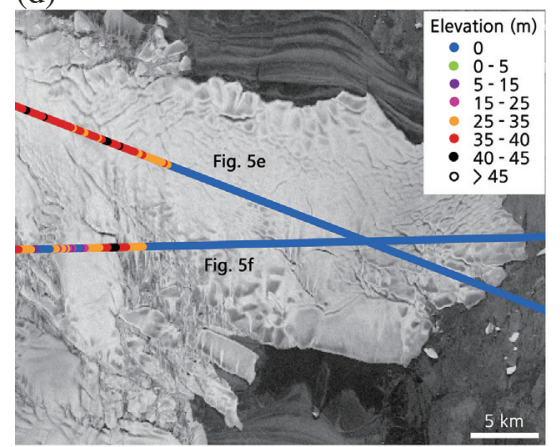

(b)

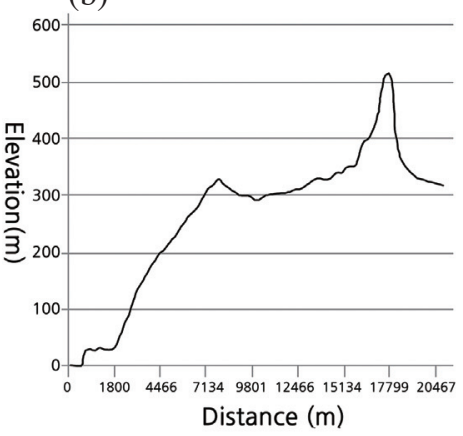

(e)

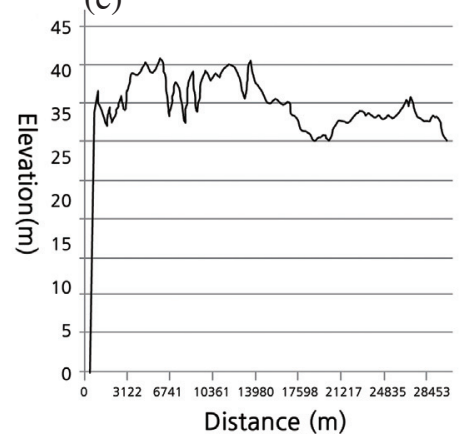

(c)
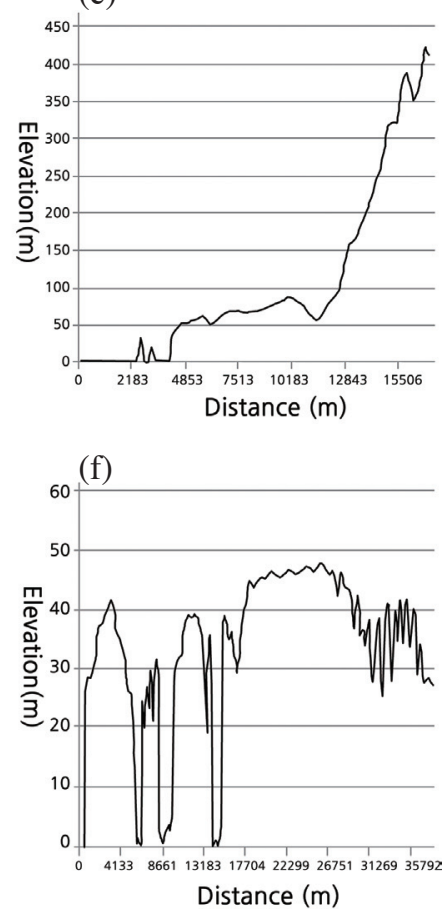

Fig. 5. Two different types of outlet glacier profiles: (a) ICESat laser altimetry profiles of the Lille glacier overlaid on MAMM data; (b), (c) representative ICESat laser altimetry profile of the Lille glacier; (d) ICESat laser altimetry profiles of the Scott glacier overlaid on MAMM data; (e), (f) representative ICESat laser altimetry profile of the Scott glacier. (Color online only) 
from -0.001 to 0.13 to $-0.06^{\circ}$. Depending on the location the surface undulation magnitude and depth vary significantly, while the general slope change tendency is similar. Most of the outlet glaciers experience very active iceberg calving at the terminus; thus, this type of profile is common for outlet glaciers. The iceberg production changes significantly in both time and space depending on complex interactions that include the outlet glacier velocity, degree of crevassing, temperature, extent, tidal forcing, and ocean waves. The length of the floating part consequently varies considerably by location and time (Løset and Carstens 1993).

The relationship between ice velocity and the outlet glacier topographic parameters was tested in the present study. Figures $6 \mathrm{a}$ and $\mathrm{b}$ show that ice velocity and ice margin slope and elevation have negative relationships, but the correlation values are very low $\left(\mathrm{R}^{2}\right.$ value is 0.1402 and 0.2492). This indicates that topographic parameters alone cannot explain the ice dynamics, as the ice dynamics of outlet glaciers are more complicated. Further studies that consider more parameters are required to determine the relationship between the morphology and ice dynamics of outlet glaciers.

\section{CONCLUSIONS}

The morphological characteristics of Antarctic ice shelves and outlet glaciers were analyzed and quantified based on ICESat laser altimetry data. The bottom up segmentation algorithm effectively extracted topographic profiles and identified the topographic parameters of the Antarctic ice margin. The ice shelves had an average boundary elevation of $29.5 \mathrm{~m}$ and a slope of $7.8^{\circ}$. From the coast margin to the inner side of the ice shelves, the slope showed a decreasing pattern from 0.4 to $1.2^{\circ}$ at $5 \mathrm{~km}$ distance. The ice shelves had a high ice margin elevation of $48.5 \mathrm{~m}$ and a long ice margin distance of $18.4 \mathrm{~km}$. The ice margin slope of the ice shelves was $0.51^{\circ}$, which indicated that the ice shelf surface profile was relatively flat and the number of ice shelf segments is 3.2 indicating relatively smaller topo- graphic variation. The outlet glaciers had an average boundary elevation of $29.7 \mathrm{~m}$ and boundary slope of $7.4^{\circ}$. The outlet glacier slope value changed from 7.4 to 1.5 to -0.1 to $0.18^{\circ}$. The outlet glaciers commonly showed alternative changes in positive and negative slope with a gentle bumpy profile shape whereas the ice shelves had a gentle increasing slope pattern with a nearly flat profile shape from the ice boundary to the inner side. The ice margin elevation of the outlet glaciers was $40 \mathrm{~m}$, with a slope of $0.07^{\circ}$, and they had a shorter ice margin distance of $10.4 \mathrm{~km}$, and large topographic variation with 5.03 for the number of segments. The outlet glaciers can be divided into 2 types. The first type discharges ice directly into the ocean without floating. Examples are the Lille, Denman, Dibble, and Underwood glaciers. This type of outlet glacier had a higher ice margin slope, a shorter ice margin distance and a concave surface profile shape. The second type was characterized by an ice stream that discharged from the outlet glacier and floated and extended into the ocean. Examples are the Scott, Williamson glaciers, and Bulter inlet. This type of outlet glacier has a much shorter ice margin distance, positive and negative slope changes and a large number of segments. The ice margin morphology shows distinctive characteristics depending on the major ice loss process.

Acknowledgements This work was supported by the National Research Foundation of Korea Grant, funded by the Korean Government under Grant NRF-2012R1A1A104589.

\section{REFERENCES}

Bamber, J. L. and A. J. Payne, 2004: Mass Balance of the Cryosphere: Observations and Modelling of Contemporary and Future Changes, Cambridge University Press, 662 pp, doi: 10.1017/CBO9780511535659. [Link]

Bodge, K. R., 1992: Representing equilibrium beach profiles with an exponential expression. J. Coast. Res., 8 , 47-55.

Bruun, P., 1954: Coast erosion and the development of (a)

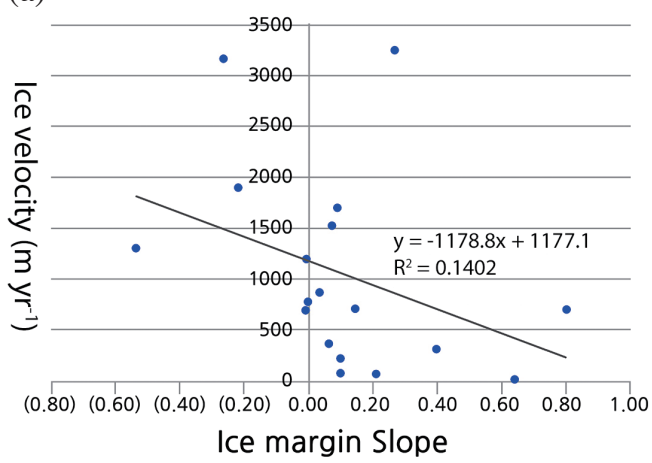

(b)

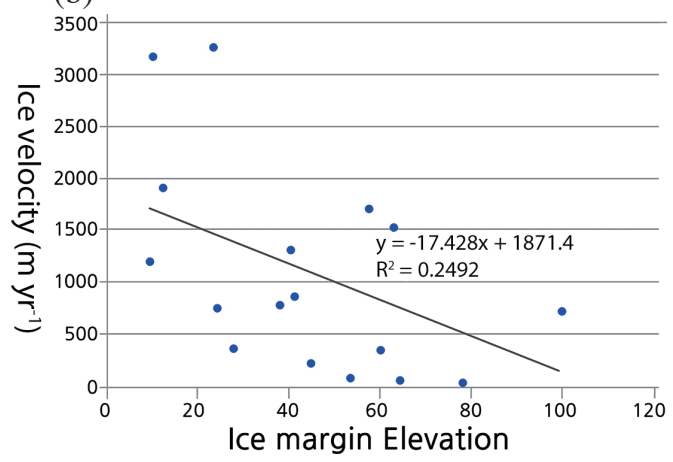

Fig. 6. Scatterplots of ice velocity and topographic parameters of outlet glaciers; (a) ice margin slope, (b) ice margin elevation. (Color online only) 
beach profiles. Technical Memorandum, Beach Erosion Board, no. 44, United States.

Cook, A. J., A. J. Fox, D. G. Vaughan, and J. G. Ferrigno, 2005: Retreating glacier fronts on the Antarctic Peninsula over the past half-century. Science, 308, 541-544, doi: 10.1126/science.1104235. [Link]

Dean, R. G., 1977: Equilibrium beach profiles: US Atlantic and Gulf coasts. Department of Civil Engineering and College of Marine Studies, University of Delaware.

Dean, R. G., 1991: Equilibrium beach profiles: Characteristics and applications. J. Coast. Res., 7, 53-84.

Drewry, D. J. and A.P. R. Cooper, 1981: Processes and models of Antarctic glaciomarine sedimentation. Ann. Glaciol., 2, 117-122, doi: 10.3189/172756481794352478. [Link]

Drewry, D. J. and G. D. Q. Robin, 1983: Form and flow of the Antarctic ice sheet during the last million years. The Climate Record in Polar Ice Sheets, 28-38.

Echelmeyer, K., R. Wade, and A. Iken, 1991: Mechanisms of ice stream motion: Jakobshavns Isbree, Greenland. Eos, Trans., $A G U, 7,44$.

Fahnestock, M. and J. Bamber, 2001: Morphology and Surface Characteristics of the West Antarctic Ice Sheet. In: Alley, R. B. and R. A. Bindschadle (Eds.), The West Antarctic Ice Sheet: Behavior and Environment, American Geophysical Union, Washington, D. C.,1327, doi: 10.1029/AR077p0013. [Link]

Fox, A. J., A. Paul, and R. Cooper, 1994: Measured properties of the Antarctic ice sheet derived from the SCAR Antarctic digital database. Polar Rec., 30, 201-206, doi: 10.1017/S0032247400024268. [Link]

Fricker, H. A., J.N. Bassis, B. Minster, and D. R. MacAyeal, 2005: ICESat's new perspective on ice shelf rifts: The vertical dimension. Geophys. Res. Lett., 32, L23S08, doi: 10.1029/2005GL025070. [Link]

Huang, J., J. Tang, M. Zhang, X. Zhang, and T. Han, 2015: An improved EMD based on cubic spline interpolation of extremum centers. J. Vibroengineering, 17, 23932409.

Huang, J. D., D. W. T. Jackson, and J. A. G. Cooper, 2010: Piecewise polynomial expression of beach profiles. J. Coast. Res., 26, 851-859, doi: 10.2112/08-1122.1. [Link]

Jenkins, A. and C. S. M. Doake, 1991: Ice-ocean interaction on Ronne Ice Shelf, Antarctica. J. Geophys. Res., 96, 791-813, doi: 10.1029/90JC01952. [Link]

Jezek, K. C., 2008: RADARSAT-1 Antarctic Mapping Project, BYRD Polar Research Center, Rep.22.

Jezek, K. C., K. Farness, R. Carande, X. Wu, and N. Labelle-Hamer, 2003: RADARSAT 1 synthetic aperture radar observations of Antarctica: Modified Antarctic Mapping Mission, 2000. Radio Sci., 38, doi: 10.1029/2002RS002643. [Link]

Kichak, R. A., 2003: Independent GLAS anomaly review board executive summary. Goddard Space Flight Center, Greenbelt, Maryland, USA. Available at http://icesat.gsfc.nasa.gov/icesat/docs/IGARB.pdf.

Komar, P. D. and W. G. McDougal, 1994: The analysis of exponential beach profiles. J. Coast. Res., 10, 59-69.

Kwok, R., H. J. Zwally, and D. Yi, 2004: ICESat observations of Arctic sea ice: A first look. Geophys. Res. Lett., 31, L16401, doi: 10.1029/2004GL020309. [Link]

Larson, M., N. C. Kraus, and R. A. Wise, 1999: Equilibrium beach profiles under breaking and non-breaking waves. Coast. Eng., 36, 59-85, doi: 10.1016/S03783839(98)00049-0. [Link]

Lemke, P., J. Ren, R. B. Alley, I. Allison, J. Carrasco, G. Flato, Y. Fujii, G. Kaser, P. Mote, R. H. Thomas, and T. Zhang, 2007: Observations: Changes in snow, ice and frozen ground. In: Solomon, S., D. Qin, M. Manning, Z. Chen, M. Marquis, K. B. Averyt, M. Tignor, and H. L. Miller (Eds.), Climate Change 2007: The Physical Science Basis, Contribution of Working Group I to the Fourth Assessment Report of the Intergovernmental Panel on Climate Change, Cambridge University Press, Cambridge, United Kingdom and New York, NY, USA, 337-383.

Løset, S. and T. Carstens, 1993: Production of icebergs and observed extreme drift speeds in the Barents Sea. Proceedings of the 12th International Conference on Port and Ocean Engineering under Arctic Conditions (POAC), Hamburg, Vol. 1, 425-438.

Marshall, S. J., G. K. C. Clarke, A. S. Dyke, and D. A. Fisher, 1996: Geologic and topographic controls on fast flow in the Laurentide and Cordilleran Ice Sheets. J. Geophys. Res., 101, 17827-17839, doi: 10.1029/96JB01180. [Link]

Massom, R. and D. Lubin, 2006: Polar Remote Sensing, Volume II: Ice Sheets, Springer-Verlag Berlin Heidelberg, 426 pp, doi: 10.1007/3-540-30565-3. [Link]

Paterson, W. S. B., 1994: The Physics of Glaciers, $3^{\text {rd }}$ Ed., Elsevier, New York.

Rémy, F. and J. F. Minster, 1997: Antarctica ice sheet curvature and its relation with ice flow and boundary conditions. Geophys. Res. Lett., 24, 1039-1042, doi: 10.1029/97GL00959. [Link]

Rignot, E., J. Mouginot, and B. Scheuchl, 2011: Ice flow of the Antarctic Ice Sheet. Science, 333, 1427-1430, doi: 10.1126/science.1208336. [Link]

Robin, G. D. Q., C. S. M. Doake, H. Kohnen, R. D. Crabtree, S. R. Jordan, and D. Möller, 1983: Regime of the Filchner-Ronne ice shelves, Antarctica. Nature, 302, 582-586, doi: 10.1038/302582a0. [Link]

Schutz, B. E., H. J. Zwally, C. A. Shuman, D. Hancock, and J. P. DiMarzio, 2005: Overview of the ICESat Mission. Geophys. Res. Lett., 32, L21S01, doi: 10.1029/2005GL024009. [Link]

Shuman, C. A., H. J. Zwally, B. E. Schutz, A. C. Brenner, J. 
P. DiMarzio, V. P. Suchdeo, and H. A. Fricker, 2006: ICESat Antarctic elevation data: Preliminary precision and accuracy assessment. Geophys. Res. Lett., 33, L07501, doi: 10.1029/2005GL025227. [Link]

Vaughan, D. G., J. C. Comiso, I. Allison, J. Carrasco, G. Kaser, R. Kwok, P. Mote, T. Murray, F. Paul, J. Ren, E. Rignot, O. Solomina, K. Steffen, and T. Zhang, 2013: Observations: Cryosphere. In: Stocker, T. F., D. Qin, G. K. Plattner, M. Tignor, S. K. Allen, J. Boschung, A. Nauels, Y. Xia, V. Bex, and P. M. Midgley (Eds.), Climate Change 2013: The Physical Science Basis, Contribution of Working Group I to the Fifth Assessment Report of the Intergovernmental Panel on Climate Change, Cambridge University Press, Cambridge, United Kingdom and New York, NY, USA., 317-382.

Wang, L. and J. Yu, 2011: Spatiotemporal segmentation of spaceborne passive microwave data for change detection. IEEE Geosci. Rem. Sens. Lett., 8, 909-913, doi: 10.1109/LGRS.2011.2140312. [Link]

Wang, P. and R. A. Davis Jr., 1998: A beach profile model for a barred coast-Case study from Sand Key, WestCentral Florida. J. Coast. Res., 14, 981-991.

Williams, R. S. and J. G. Ferrigno, 1998: Satellite image atlas of glaciers of the world: South America. U.S. Geological Survey Professional Paper 1386-I, U.S.
Geological Survey, 206 pp.

Wouters, B, J. L. Bamber, M. R. van den Broeke, J. T. M. Lenaerts, and I. Sasgen, 2013: Limits in detecting acceleration of ice sheet mass loss due to climate variability. Nat. Geosci., 6, 613-616, doi: 10.1038/ngeo1874. [Link]

Yi, D., X. Sun, and H. J. Zwally, 2003: A study of the GLAS echo waveform using ground test data. EGS-AGUEUG Joint Assembly, abstract \#13690, Nice, France.

Young, D. A., L. E. Lindzey, D. D. Blankenship, J. S. Greenbaum, A. G. De Gorordo, S. D. Kempf, J. L. Roberts, R. C. Warner, T. Van Ommen, M. J. Siegert, and E. Le Meur, 2015: Land-ice elevation changes from photon-counting swath altimetry: First applications over the Antarctic ice sheet. J. Glaciol., 61, 1728, doi: 10.3189/2015JoG14J048. [Link]

Yu, J., H. Liu, K. C. Jezek, R. C. Warner, and J. Wen, 2010: Analysis of velocity field, mass balance, and basal melt of the Lambert Glacier-Amery Ice Shelf system by incorporating Radarsat SAR interferometry and ICESat laser altimetry measurements. J. Geophys. Res., 115, B11102, doi: 10.1029/2010JB007456. [Link]

Zwally, H. J., D. Yi, R. Kwok, and Y. Zhao, 2008: ICESat measurements of sea ice freeboard and estimates of sea ice thickness in the Weddell Sea.J. Geophys. Res., 113, C02S15, doi: 10.1029/2007JC004284. [Link] 